\title{
Correction to: Do modern stock exchanges emerge from competition? Evidence from the "Belgian Big Bang"
}

\section{Tom Duterme ${ }^{1}$}

Published online: 14 February 2022

(C) European Association for Evolutionary Political Economy 2022

\section{Correction to: Review of Evolutionary Political Economy}

https://doi.org/10.1007/s43253-022-00,069-4

Due to a typesetting error in the layout of the reference list in the article "Do modern stock exchanges emerge from competition? Evidence from the "Belgian Big Bang" https://link.springer.com/article/10.1007/s43253-022-00,069-4, the reference "- (2022) Pourquoi ici et maintenant ? La transformation des marchés financiers belges à l'aune du réalisme critique de Margaret Archer. Louvain Papers on Democracy \& Society 83" is attributed to Coenjaerts T, while it is written by Duterme T.

So, the line "—_ (2022) Pourquoi ici et maintenant ? La transformation des marchés financiers belges à l'aune du réalisme critique de Margaret Archer. Louvain Papers on Democracy \& Society 83" should be included under the line "Duterme T (2021) Comment émerge un indice boursier ? Histoire du BEL 20. Revue Française De Socio-Économie 27:157-174." and linked with the quote in footnote 7 ("For a discussion, based on Margaret Archer's model, of other elements (including the horizon of the single European market and financial computerisation), see Duterme (2022).").

The original article has been updated.

The original article can be found online at https://doi.org/10.1007/s43253-022-00069-4.

Tom Duterme

tom.duterme@uclouvain.be

1 FNRS, Centre de Recherches Interdisciplinaires, Démocratie, Institutions, Subjectivité (CriDIS) \& Louvain Finance (LFIN), Catholic University of Louvain, Louvain-la-Neuve, Ottignies-Louvain-la-Neuve, Belgium 